\title{
Vibrational Studies of the Disulfide Group in Proteins. Part V. Correlation of SS Stretch Frequencies with the CCSS Dihedral Angle in Known Protein Disulfide Bridges
}

\author{
WEILI QIAN and SAMUEL KRIMM
}

Biophysics Research Division and Department of Physics, University of Michigan, Ann Arbor, Michigan 48109

\begin{abstract}
SYNOPSIS
Normal mode calculations have been done on 92 disulfide bridges in 25 known protein structures in order to correlate the SS stretch frequency with the CCSS dihedral angle. It is possible to classify the frequencies into four major categories, which provide a more detailed classification scheme than previously proposed from dialkyl disulfide correlations.
\end{abstract}

\section{INTRODUCTION}

Early alkyl disulfide studies ${ }^{1}$ had established that the frequency of the Raman-active SS stretch mode, $\nu$ (SS), is correlated with the CCSS dihedral angle, $\chi^{2}: \nu$ (SS) was found near 510,525 , or $540 \mathrm{~cm}^{-1}$ when the conformation had two, one, or no $\mathrm{H}$ atoms, respectively, trans to distal $\mathrm{S}$ atoms across the CS bond.

While such a relation may provide a rough spectrum-structure correlation, it cannot capture the subtleties of $\mathrm{S}-\mathrm{S}$ bridge conformations in proteins, such as the dependence of $\nu$ (SS) on $\chi^{2} \neq \pm 60^{\circ}, 180^{\circ}$, as well as possible changes due to variations in the NCCS dihedral angle, $\chi^{1}$, and in the $\phi$ and $\psi$ of the adjacent peptide groups. Such effects can only be revealed by reliable normal mode calculations on the relevant structures.

We have obtained a conformation-dependent force field for the disulfide group by scaling ab initio force constants to experimental frequencies of alkyl disulfides. ${ }^{2-4}$ When combined with an empirical force field for the peptide group,${ }^{5}$ calculated $\nu$ (SS) frequencies of SS bridges in seven known peptide and protein structures are found to be in very good agreement with observed Raman bands associated with these modes. ${ }^{6}$ This combined force field thus provides a sound basis for studying the structurespectrum relationship referred to above. ${ }^{1}$

Biopolymers, Vol. 32, 321-326 (1992)

(C) 1992 John Wiley \& Sons, Inc.

CCC 0006-3525/92/040321-06\$04.00
As a guide to a more extensive vibrational study of the $\chi^{2}, \chi^{1}, \phi, \psi$, conformational space of the disulfide group, ${ }^{7}$ we have chosen to examine first the spectral characteristics of known protein S-S bridges. These structures are an indication of the kinds of conformations that may be common in proteins, and a classification of their $\nu$ (SS) frequencies would therefore be useful in establishing preliminary correlations as well as in providing the basis for further spectral studies of these proteins.

A recent survey has been made of the geometric characteristics of $72 \mathrm{~S}-\mathrm{S}$ bridges in 22 proteins, ${ }^{8}$ and these were found to fall into eight families based on $\mathrm{C}^{\alpha}-\mathrm{C}^{\alpha}$ and $\mathrm{C}^{\beta}-\mathrm{C}^{\beta}$ distances and the chirality of the bridge (the CSSC dihedral angle, $\chi^{3}$, is usually near $90^{\circ}$, with about an equal number of righthanded and left-handed bridges). We have calculated the $\nu(\mathrm{SS})$ of $92 \mathrm{~S}-\mathrm{S}$ bridges in 25 proteins, whose structures were taken from the Protein Data Bank $^{9}$ ( 55 were the same as in Ref. 8), and although the above classification ${ }^{8}$ is not relevant for vibrational frequencies, we find that the $\nu(\mathrm{SS})$ fall into reasonably well-defined classes, in several respects significantly different from those given earlier. ${ }^{1}$

\section{CALCULATIONS}

As in our previous study, ${ }^{6}$ normal mode calculations were performed on the unit $\left[\mathrm{SCH}_{2} \mathrm{CH}\right.$ (CONHC) (NHCOC) $]_{2}$. Values for all 9 dihedral angles-viz., $\phi_{1}, \psi_{1}, \chi_{1}^{1}, \chi_{1}^{2}, \chi^{3}, \chi_{2}^{2}, \chi_{2}^{1}, \phi_{2}, \psi_{2}$-were 
Table I Calculated SS Stretch Frequencies $\left(\right.$ in $\mathrm{cm}^{-1}$ ) of Disulfide Bridges in Proteins

\begin{tabular}{|c|c|c|c|c|c|c|}
\hline Type & $\chi_{1}^{2} \chi_{2}^{2 a}$ & $\chi_{1}^{1} \chi_{2}^{1 b}$ & Chir $^{c}$ & $v(S S)^{d}$ & Protein $^{e}$ & Bridge $^{f}$ \\
\hline \multirow[t]{3}{*}{1} & $\mathrm{G}^{\prime} \mathrm{G}$ & $\mathrm{CN}$ & $\mathbf{R}$ & $503(91)$ & 1BP2 & $61-91$ \\
\hline & $\mathrm{G}^{\prime} \mathrm{G}$ & $\mathrm{CN}$ & $\mathbf{R}$ & $505(91)$ & $20 \mathrm{OV}$ & $24-56$ \\
\hline & $G^{\prime} G$ & $\mathrm{CN}$ & $\mathbf{R}$ & $504(95)$ & $1 \mathrm{SN} 3$ & $12-65$ \\
\hline \multirow[t]{5}{*}{2} & $\mathrm{~GB}^{\prime}$ & $\mathrm{CN}$ & $\mathrm{L}$ & $505(88)$ & 9PAP & $22-63$ \\
\hline & $\mathrm{GB}^{\prime}$ & $\mathrm{NC}$ & $\mathrm{R}$ & $504(91)$ & 9PAP & $56-95$ \\
\hline & $\mathrm{GB}^{\prime}$ & $\mathrm{CC}$ & $\mathrm{R}$ & $503(92)$ & $1 \mathrm{TPP}$ & $22-157$ \\
\hline & $\mathrm{GB}^{\prime}$ & $\mathrm{NC}$ & $\mathbf{R}$ & $507(93)$ & 3INS & $\mathrm{A} 7-\mathrm{B} 7$ \\
\hline & $\mathrm{GB}^{\prime}$ & $\mathrm{NC}$ & $\mathbf{R}$ & $505(90)$ & 3INS & $\mathrm{C} 7-\mathrm{D} 7$ \\
\hline \multirow[t]{4}{*}{3} & $\mathrm{G}^{\prime} \mathrm{B}$ & $\mathrm{CH}$ & $\mathrm{R}$ & $506(82)$ & 1ZL1 & $65-81$ \\
\hline & $\mathrm{G}^{\prime} \mathrm{B}$ & $\mathrm{CC}$ & $\mathbf{R}$ & $504(85)$ & 5RSA & $65-72$ \\
\hline & $\mathrm{G}^{\prime} \mathrm{B}$ & $\mathrm{CH}$ & $\mathbf{R}$ & $512(78)$ & $2 \mathrm{SGA}$ & $191-220$ \\
\hline & G'B & $\mathrm{CC}$ & $\mathrm{R}$ & $505(73)$ & $3 \mathrm{RP2}$ & A168-A182 \\
\hline 4 & $\mathrm{~B}^{\prime} \mathrm{B}$ & $\mathrm{CC}$ & $\mathbf{R}$ & $503(90)$ & $2 \mathrm{APP}$ & $249-283$ \\
\hline \multirow[t]{2}{*}{5} & $\mathbf{B}^{\prime} \mathbf{B}^{\prime}$ & $\mathrm{CC}$ & $\mathbf{R}$ & $506(98)$ & 1TPP & $136-201$ \\
\hline & $\mathbf{B}^{\prime} \mathbf{B}^{\prime}$ & $\mathrm{CC}$ & $\mathrm{R}$ & $506(97)$ & 2ALP & $137-159$ \\
\hline \multirow[t]{10}{*}{6} & GG & $\mathrm{CC}$ & $\mathrm{L}$ & $507(87)$ & 5RSA & $40-95$ \\
\hline & GG & $\mathrm{NC}$ & $\mathbf{R}$ & $506(88)$ & $1 \mathrm{TPP}$ & $168-182$ \\
\hline & GG & $\mathrm{CC}$ & $\mathrm{L}$ & $509(87)$ & 2AZA & A3-A26 \\
\hline & GG & $\mathrm{CC}$ & $\mathrm{L}$ & $509(95)$ & $2 \mathrm{AZA}$ & $\mathrm{B} 3-\mathrm{B} 26$ \\
\hline & $\mathrm{GG}$ & $\mathrm{CC}$ & $\mathrm{L}$ & $508(97)$ & 3EBX & $3-24$ \\
\hline & GG & $\mathrm{CC}$ & $\mathrm{L}$ & $507(92)$ & $1 \mathrm{NXB}$ & $17-41$ \\
\hline & GG & $\mathrm{CC}$ & $\mathrm{L}$ & $508(93)$ & 3INS & A20-B19 \\
\hline & GG & $\mathrm{CC}$ & $\mathrm{L}$ & $507(71)$ & $20 \mathrm{VO}$ & $8-38$ \\
\hline & GG & $\mathrm{CC}$ & $\mathrm{L}$ & $507(87)$ & $1 \mathrm{SN} 3$ & $25-46$ \\
\hline & $\mathrm{GG}$ & NN & $\mathbf{R}$ & $508(93)$ & $1 \mathrm{SN} 3$ & $29-48$ \\
\hline \multirow[t]{13}{*}{7} & GB & $\mathrm{CN}$ & $\mathrm{L}$ & $508(88)$ & 1LZ1 & $30-116$ \\
\hline & GB & $\mathrm{CC}$ & $\mathrm{L}$ & $506(84)$ & $5 \mathrm{RSA}$ & $26-84$ \\
\hline & GB & $\mathrm{CC}$ & $\mathrm{L}$ & $508(97)$ & 1CRN & $3-40$ \\
\hline & GB & $\mathrm{CN}$ & $\mathrm{L}$ & $509(93)$ & $1 \mathrm{CRN}$ & $16-26$ \\
\hline & GB & $\mathrm{CC}$ & L & $506(94)$ & $5 \mathrm{PTI}$ & $5-55$ \\
\hline & $\mathrm{GB}$ & $\mathrm{CC}$ & $\mathrm{L}$ & $510(96)$ & 3EBX & $17-41$ \\
\hline & GB & $\mathrm{CC}$ & $\mathrm{L}$ & $510(97)$ & $1 \mathrm{NXB}$ & $3-24$ \\
\hline & GB & $\mathrm{CC}$ & $\mathrm{L}$ & $511(82)$ & $1 \mathrm{BP} 2$ & $27-123$ \\
\hline & GB & $\mathrm{CN}$ & $\mathrm{L}$ & $508(92)$ & 1BP2 & $44-105$ \\
\hline & GB & $\mathrm{CN}$ & $\mathrm{L}$ & $508(90)$ & $1 \mathrm{BP} 2$ & $51-98$ \\
\hline & $\mathrm{GB}$ & $\mathrm{CN}$ & $\mathrm{L}$ & $509(95)$ & $20 \mathrm{VO}$ & $16-35$ \\
\hline & GB & $\mathrm{NH}$ & $\mathrm{R}$ & $510(84)$ & $1 \mathrm{SN} 3$ & $16-41$ \\
\hline & GB & $\mathrm{NC}$ & $\mathrm{R}$ & $510(90)$ & 3RP2 & B168-B182 \\
\hline 8 & $\mathrm{SB}^{\prime}$ & $\mathrm{NH}$ & $\mathrm{R}$ & $510(85)$ & $3 \mathrm{FAB}$ & L213-H220 \\
\hline \multirow[t]{8}{*}{9} & $B^{\prime} S^{\prime}$ & $\mathrm{CC}$ & $\mathrm{R}$ & $510(96)$ & $1 \mathrm{ACX}$ & $34-43$ \\
\hline & $B^{\prime} S^{\prime}$ & $\mathrm{CC}$ & $\mathrm{R}$ & $510(91)$ & $3 \mathrm{RP} 2$ & A136-A201 \\
\hline & $\mathrm{B}^{\prime} \mathrm{S}^{\prime}$ & $\mathrm{CC}$ & $\mathrm{R}$ & $509(92)$ & 4CHA & A136-A201 \\
\hline & $\mathrm{B}^{\prime} \mathrm{S}^{\prime}$ & $\mathrm{CC}$ & $\mathrm{R}$ & $509(95)$ & $4 \mathrm{CHA}$ & B136-B201 \\
\hline & $\mathrm{B}^{\prime} \mathrm{S}^{\prime}$ & $\mathrm{CC}$ & $\mathrm{R}$ & $511(96)$ & $2 \mathrm{CGA}$ & A136-A201 \\
\hline & $\mathrm{B}^{\prime} \mathrm{S}^{\prime}$ & $\mathrm{CC}$ & $\mathrm{R}$ & $511(97)$ & $2 \mathrm{CGA}$ & B136-B201 \\
\hline & $\mathrm{B}^{\prime} \mathrm{S}^{\prime}$ & $\mathrm{CC}$ & $\mathrm{R}$ & $509(95)$ & $1 \mathrm{CRN}$ & $4-32$ \\
\hline & $\mathrm{B}^{\prime} \mathrm{S}^{\prime}$ & $\mathrm{NC}$ & $\mathrm{L}$ & $507(88)$ & 3GRS & $58-63$ \\
\hline \multirow[t]{5}{*}{10} & $\mathrm{BB}$ & $\mathrm{HH}$ & $\mathrm{R}$ & $510(87)$ & $3 \mathrm{EBX}$ & $55-60$ \\
\hline & $\mathrm{BB}$ & $\mathrm{HH}$ & $\mathrm{R}$ & $519(75)$ & $1 \mathrm{NXB}$ & $55-60$ \\
\hline & BB & $\mathrm{NN}$ & $\mathrm{R}$ & $505(87)$ & 1BP2 & $11-77$ \\
\hline & $\mathrm{BB}$ & $\mathrm{CN}$ & $\mathrm{L}$ & $508(86)$ & $1 \mathrm{BP} 2$ & $84-96$ \\
\hline & $\mathrm{BB}$ & $\mathrm{CN}$ & $\bar{L}$ & $513(89)$ & 5PTI & $30-51$ \\
\hline \multirow[t]{2}{*}{11} & GA & $\mathrm{CC}$ & $\mathrm{L}$ & $510(86)$ & 3INS & C20-D19 \\
\hline & $\mathrm{GA}$ & $\mathrm{CC}$ & $\mathrm{L}$ & $511(92)$ & $1 \mathrm{LZ1}$ & $6-128$ \\
\hline 12 & $\mathbf{S S}^{\prime}$ & $\mathrm{CH}$ & $\mathrm{R}$ & $507(66)$ & $5 \mathrm{PTI}$ & $14-38$ \\
\hline 13 & GS & $\mathrm{CC}$ & $\mathrm{L}$ & $514(91)$ & $5 \mathrm{RSA}$ & $58-110$ \\
\hline \multirow[t]{3}{*}{14} & $\mathrm{G}^{\prime} \mathrm{D}$ & $\mathrm{CC}$ & $\mathrm{R}$ & $516(77)$ & $1 \mathrm{BP} 2$ & $29-45$ \\
\hline & $\mathrm{G}^{\prime} \mathrm{D}$ & $\mathrm{CC}$ & $\mathrm{R}$ & $513(63)$ & $5 \mathrm{CPA}$ & $138-161$ \\
\hline & $G^{\prime} D$ & $\mathrm{CH}$ & $\mathrm{R}$ & $517(78)$ & $1 \mathrm{TPP}$ & $128-232$ \\
\hline
\end{tabular}


Table I (Continued)

\begin{tabular}{|c|c|c|c|c|c|c|}
\hline Type & $\chi_{1}^{2} \chi_{2}^{2 a}$ & $\chi_{1}^{1} \chi_{2}^{1 \mathrm{~b}}$ & Chir $^{c}$ & $v(S S)^{d}$ & Protein $^{e}$ & Bridge $^{f}$ \\
\hline \multirow[t]{2}{*}{15} & $\mathrm{GD}^{\prime}$ & $\mathrm{CH}$ & $\mathbf{R}$ & $519(54)$ & 3INS & C6-C11 \\
\hline & $\mathbf{G}^{\prime} \mathbf{D}^{\prime}$ & $\mathrm{CC}$ & $\mathrm{R}$ & $512(80)$ & 3RP2 & B136-B201 \\
\hline \multirow[t]{8}{*}{16} & $\mathrm{BD}$ & $\mathrm{CC}$ & $\mathrm{L}$ & $517(84)$ & $1 T P P$ & $42-58$ \\
\hline & $\mathrm{BD}$ & $\mathrm{CC}$ & $\mathrm{L}$ & $518(68)$ & 2ALP & $42-58$ \\
\hline & $\mathrm{BD}$ & $\mathrm{CC}$ & $\mathrm{L}$ & $519(69)$ & 3RP2 & $\mathrm{A} 42-\mathrm{A} 58$ \\
\hline & $\mathrm{BD}$ & $\mathrm{CC}$ & L & $519(77)$ & $3 \mathrm{RP} 2$ & B42-B58 \\
\hline & $\mathrm{BD}$ & $\mathrm{CC}$ & $\mathrm{L}$ & $519(84)$ & 4CHA & A42-A58 \\
\hline & $\mathrm{BD}$ & $\mathrm{CC}$ & $\mathrm{L}$ & $519(85)$ & 4CHA & B42-B58 \\
\hline & $\mathrm{BD}$ & $\mathrm{CC}$ & $\mathbf{L}$ & $518(84)$ & 2CGA & A42-A58 \\
\hline & $\mathrm{BD}$ & $\mathrm{CC}$ & $\mathbf{L}$ & $517(84)$ & 2CGA & B42-B58 \\
\hline \multirow[t]{2}{*}{17} & $\mathrm{~B}^{\prime \prime} \mathrm{T}$ & $\mathrm{CH}$ & $\mathbf{R}$ & $529(25)$ & $2 \mathrm{CGA}$ & A $191-A 220$ \\
\hline & & & & $518(51)$ & & \\
\hline 18 & $\mathrm{AT}$ & $\mathrm{CH}$ & $\mathrm{L}$ & $526(65)$ & 9PAP & $153-200$ \\
\hline \multirow[t]{2}{*}{19} & $\mathrm{G}^{\prime} \mathrm{T}$ & $\mathrm{CH}$ & $\mathbf{R}$ & $524(55)$ & 3INS & A6-A11 \\
\hline & & & & $468(22)$ & & \\
\hline \multirow[t]{7}{*}{20} & GT & $\mathrm{NC}$ & $\mathrm{R}$ & $528(81)$ & $4 \mathrm{CHA}$ & A191-A220 \\
\hline & GT & $\mathrm{NC}$ & $\mathrm{R}$ & $524(83)$ & $1 \mathrm{LZ} 1$ & $77-95$ \\
\hline & GT & $\mathrm{NC}$ & $\mathrm{R}$ & $521(74)$ & 1TPP & $191-220$ \\
\hline & GT & $\mathrm{NC}$ & $\mathrm{R}$ & $527(75)$ & 3EBX & $43-54$ \\
\hline & GT & $\mathrm{CC}$ & $\mathbf{L}$ & $527(70)$ & $1 \mathrm{ACX}$ & $83-88$ \\
\hline & GT & $\mathrm{NC}$ & $\mathrm{R}$ & $529(80)$ & $4 \mathrm{CHA}$ & $\mathrm{B} 191-\mathrm{B} 220$ \\
\hline & GT & $\mathrm{CC}$ & $\mathrm{L}$ & $521(79)$ & 2CGA & B191-B220 \\
\hline \multirow[t]{4}{*}{21} & $\mathrm{D}^{\prime \prime} \mathrm{T}$ & $\mathrm{NC}$ & $\mathrm{L}$ & $537(26)$ & $4 \mathrm{CHA}$ & A168-A182 \\
\hline & & & & $526(49)$ & & \\
\hline & $\mathrm{D}^{\prime \prime} \mathrm{T}$ & $\mathrm{NC}$ & $\mathrm{L}$ & $539(24)$ & $4 \mathrm{CHA}$ & B168-B182 \\
\hline & & & & $526(47)$ & & \\
\hline \multirow[t]{10}{*}{22} & SD & $\mathrm{NH}$ & $\mathrm{R}$ & $557(21)$ & $3 \mathrm{FAB}$ & L22-L87 \\
\hline & & & & $526(56)$ & & \\
\hline & $\mathrm{SD}$ & $\mathrm{CC}$ & $\mathrm{L}$ & $535(29)$ & 2SGA & $42-58$ \\
\hline & & & & $516(47)$ & & \\
\hline & $\mathrm{SD}$ & $\mathrm{NH}$ & $\mathrm{R}$ & $556(33)$ & 2RHE & $22-89$ \\
\hline & & & & $515(32)$ & & \\
\hline & $\mathrm{SD}$ & $\mathrm{HC}$ & $\mathrm{L}$ & $547(42)$ & 1REI & A23-A 88 \\
\hline & & & & $521(31)$ & & \\
\hline & $\mathrm{SD}$ & NH & $\mathrm{R}$ & $552(39)$ & 1REI & B23-B88 \\
\hline & & & & $518(35)$ & & \\
\hline 23 & DT & NN & $\mathrm{L}$ & $544(74)$ & $3 F A B$ & $\mathrm{H} 144-\mathrm{H} 200$ \\
\hline \multirow[t]{3}{*}{24} & BT & $\mathrm{NC}$ & $\mathrm{R}$ & $547(27)$ & $1 \mathrm{NXB}$ & $43-54$ \\
\hline & & & & $525(40)$ & & \\
\hline & & & & $506(26)$ & & \\
\hline \multirow[t]{8}{*}{25} & $\mathrm{TT}$ & NN & $\mathrm{L}$ & $551(68)$ & $3 F A B$ & L136-L195 \\
\hline & & & & $507(15)$ & & \\
\hline & $\mathrm{TT}$ & $\mathrm{NN}$ & $L$ & $549(65)$ & $3 F A B$ & $\mathrm{H} 22-\mathrm{H} 95$ \\
\hline & & & & $521(16)$ & & \\
\hline & $\mathrm{TT}$ & $\mathrm{NC}$ & $\mathrm{L}$ & $541(23)$ & $2 \mathrm{CGA}$ & A168-A182 \\
\hline & & & & $529(49)$ & & \\
\hline & $\mathrm{TT}$ & $\mathrm{NC}$ & $\mathrm{L}$ & $540(33)$ & 2CGA & B168-B182 \\
\hline & & & & $529(39)$ & & \\
\hline
\end{tabular}

${ }^{a} \mathrm{C}^{\alpha} \mathrm{C}^{\beta} \mathrm{SS}$ dihedral angles (based on right-handed $\chi^{3}$; see text): $\mathrm{C}\left(0^{\circ}\right), \mathrm{A}\left(30^{\circ}\right), \mathrm{G}\left(60^{\circ}\right), \mathrm{B}\left(90^{\circ}\right), \mathrm{S}\left(120^{\circ}\right), \mathrm{D}\left(150^{\circ}\right), \mathrm{T}\left(180^{\circ}\right) ;$ prime: negative angle.

${ }^{b} \mathrm{NC}^{\alpha} \mathrm{C}^{\beta} \mathrm{S}$ dihedral angles: $\mathrm{C}-\mathrm{C}$ trans to $\mathrm{S}\left(\chi^{2}=-60^{\circ}\right) ; \mathrm{N}-\mathrm{N}$ trans to $\mathrm{S}\left(\chi^{1}=180^{\circ}\right) ; \mathrm{H}-\mathrm{H}$ trans to $\mathrm{S}\left(\chi^{1}=60\right)$.

${ }^{c}$ Chirality of $\mathrm{S}-\mathrm{S}$ bridge: $\mathrm{R}$-right handed $\left(\chi^{3}>0\right)$; L-left-handed $\left(\chi^{3}<0\right)$.

'Numbers in parentheses: potential energy distribution in SS stretch.

Protein Data Bank Code: 1ACX, actinoxanthin; 1BP2, phospholipase A2; 1CRN, crambin; 1LZ1, lysozyme; 1NXB, neurotoxin B; 1REI, Bence-Jones protein (REI variable domain); 1SN3, scorpion neurotoxin (variant 3); 1TPP, trypsin complex with APPA; 2ALP, $\alpha$-lytic protease; 2APP, acid proteinase (penicillium J); 2AZA, azurin; 2CGA, chymotrypsinogen A; 2OVO, ovomucoid third domain; 2RHE, Bence-Jones protein ( $\lambda$, variable domain); 2SGA, proteinase A; 3EBX, erabutoxin B; 3FAB, immunoglobulin FAB*; 3GRS, glutathione reductase; 3INS, insulin (porcine); 3RP2, rat mast cell proteinase II; 4CHA, $\alpha$-chymotrypsin; 5CPA, carboxypeptidase A; 5RSA, ribonuclease A; 5PTI, trypsin inhibitor; 9PAP, papain.

Cystine residues connected by $\mathrm{S}-\mathrm{S}$ bridge. 
taken from the bridge structures in the Protein Data Bank. ${ }^{9}$ Bond lengths and angles for the peptide groups were taken as standard values, ${ }^{5}$ and the comparable quantities for the $\mathrm{S}-\mathrm{S}$ bridge were those of diethyl disulfide. ${ }^{4,6}$

The force field consisted of two parts, as in our earlier study ${ }^{6}$ : an empirical force field for the peptide group ${ }^{5}$ and an ab initio conformation-dependent force field for the S-S bridge part. ${ }^{4,6}$ In the latter, force constants were chosen in the following categories of the $\chi^{2}$ dihedral angle ${ }^{6}: \mathrm{C}\left(0^{\circ}\right), \mathrm{A}\left(30^{\circ}\right)$, $\mathrm{G}\left(60^{\circ}\right), \mathrm{B}\left(90^{\circ}\right), \mathrm{S}\left(120^{\circ}\right), \mathrm{D}\left(150^{\circ}\right), \mathrm{T}\left(180^{\circ}\right)$, $\mathrm{D}^{\prime}\left(-150^{\circ}\right), \mathrm{S}^{\prime}\left(-120^{\circ}\right), \mathrm{B}^{\prime}\left(-90^{\circ}\right), \mathrm{G}^{\prime}\left(-60^{\circ}\right)$, and $\mathrm{A}^{\prime}\left(-30^{\circ}\right)$.

\section{RESULTS AND DISCUSSION}

The $\nu$ (SS) frequencies resulting from full normal mode calculations on our model structure for each of the $92 \mathrm{~S}-\mathrm{S}$ bridges are given in Table I. The conformations are grouped according to $\chi_{1}^{2}$ and $\chi_{2}^{2}\left(\chi^{3}\right.$, which is usually designated by $\mathrm{G}$ or $\mathrm{G}^{\prime}$, has been left out, so $\mathrm{GB}^{\prime}$ would be $\mathrm{GGB}^{\prime}$ in a $\chi_{1}^{2} \chi^{3} \chi_{2}^{2}$ designation $^{6}$ ). For convenience, all conformations are listed in terms of a right-handed S-S bridge [i.e., $\left.\mathrm{G}^{\prime} \mathrm{G}^{\prime} \mathrm{B}=\mathrm{GB}^{\prime}(\mathrm{L})\right]$, although of course the calculations were done for the actual structures, ${ }^{6}$ whose chiralities are given in the table. We also give the $\chi_{1}^{1}$ and $\chi_{2}^{1}$ values for each bridge, in terms of the atoms trans to $\mathrm{S}$ across the $\mathrm{C}^{\alpha} \mathrm{C}^{\beta}$ bonds. The po- tential energy distribution (PED) of each $\nu$ (SS) mode is given in parentheses after the frequency.

The frequency ranges obtained for each of the 25 observed types are presented on a conformational map in Table II. In a few cases we find that SS stretch contributes to more than one mode of a given bridge. Following our earlier experience, ${ }^{6}$ we have included (as potentially observable) only those of such modes that have a PED for SS stretch larger than about half that of the maximum for the bridge. The conformational types are arranged in Table II in rough order of decreasing frequency ranges.

As can be seen from these tables, many conformational types are not represented. In particular, no conformations are found with $\chi^{2}=\mathrm{C}$ or $\mathrm{A}^{\prime}$, nor is $S^{\prime} S^{\prime}$ observed. These correspond to 7 of the 9 highest energy bridge structures, ${ }^{3}$ and of the other two, SS and SS', only one is found. Nor are structures with very short $\mathrm{C}^{\alpha}-\mathrm{C}^{\alpha}$ distances and intermediate energies, ${ }^{3} G^{\prime} G^{\prime}$ and $S^{\prime} G^{\prime}$, observed (although small variants of these, $\mathrm{B}^{\prime} \mathrm{B}^{\prime}$ and $\mathrm{S}^{\prime} \mathrm{B}^{\prime}$, are found). Of the remaining 5 structures of intermediate energies ${ }^{3}-\mathrm{GS}^{\prime}, \mathrm{SG}^{\prime}, \mathrm{TS}$, GS, and ST-only one $(G S)$ is found, but there are a number of observed cases in which one of the angles varies by $\sim 30^{\circ}$. All of the low-energy conformations ${ }^{3}-\mathrm{GG}^{\prime}, \mathrm{TG}^{\prime}$, GT, GG, and TT-are observed, as well as some small variants of these. Thus, while low-energy $\mathrm{S}_{-}$ $\mathrm{S}$ bridge conformations predominate in proteins, higher energy structures do occur, obviously com-

Table II Conformational Map of Calculated SS Stretch Frequency Ranges (in $\mathrm{cm}^{-1}$ ) of Disulfide Bridges in Proteins

\begin{tabular}{|c|c|c|c|c|c|c|c|c|c|c|c|c|}
\hline \multirow[b]{2}{*}{$\chi_{2}^{2 a}$} & \multicolumn{12}{|c|}{$\chi_{1}^{2 \mathrm{a}}$} \\
\hline & $\mathrm{T}$ & $\mathrm{D}$ & $\mathrm{D}^{\prime}$ & $\mathrm{C}$ & A & $\mathrm{A}^{\prime}$ & $\mathrm{S}$ & $\mathrm{S}^{\prime}$ & B & G & $\mathrm{B}^{\prime}$ & $\mathrm{G}^{\prime}$ \\
\hline $\mathrm{T}$ & $\begin{array}{c}529 \\
540-51\end{array}$ & 544 & 526 & & 526 & & & & 525 & $521-529$ & 518 & 524 \\
\hline D & & & & & & & $\begin{array}{l}515-26 \\
535-56\end{array}$ & & $517-519$ & & & $513-517$ \\
\hline $\begin{array}{l}\mathrm{D}^{\prime} \\
\mathrm{C}\end{array}$ & & & & & & & & & & & & $512-51 c$ \\
\hline A & & & & & & & & & & $510-511$ & & \\
\hline $\begin{array}{l}\mathrm{S} \\
\mathrm{S}^{\prime}\end{array}$ & & & & & & & & 507 & & 514 & $\begin{array}{c}510 \\
507-511\end{array}$ & \\
\hline B & & & & & & & & & $505-519$ & $506-511$ & 503 & $504-506$ \\
\hline $\begin{array}{l}\mathrm{G} \\
\mathrm{B}^{\prime} \\
\mathrm{G}^{\prime}\end{array}$ & & & & & & & & & & $506-509$ & $\begin{array}{c}503-507 \\
506\end{array}$ & $503-505$ \\
\hline
\end{tabular}

\footnotetext{
${ }^{a} \mathrm{C}^{\alpha} \mathrm{C}^{\beta} \mathrm{SS}$ dihedral angles (based on right-handed $\chi^{3}$; see text): $\mathrm{C}\left(0^{\circ}\right), \mathrm{A}\left(30^{\circ}\right), \mathrm{G}\left(60^{\circ}\right), \mathrm{B}\left(90^{\circ}\right), \mathrm{S}\left(120^{\circ}\right), \mathrm{D}\left(150^{\circ}\right)$, $\mathrm{T}\left(180^{\circ}\right)$; prime: negative angle.
} 
pensated by structural requirements in other parts of the protein. This means that when a protein structure changes (for whatever reasons), it can be expected that higher energy $\mathrm{S}-\mathrm{S}$ bridges may relax to lower energy local conformations. Such structural changes may be usefully monitored if we have a detailed understanding of the $\nu(\mathrm{SS})$-conformation relationship.

It is also worth noting that the frequency range for an observed conformational type is generally fairly small, indicating that there may either be a small dependence on parameters other than $\chi^{2}$ (which is not suggested by more general conformational results ${ }^{7}$ ) or that some correlations with $\chi^{1}$ (and perhaps $\chi^{1}$ with $\phi, \psi$ ) may exist. In fact, we see that of 23 GG and GB structures, 19 are of lefthanded chirality and of these 14 have $\chi_{1}^{1} \chi_{2}^{1}=\mathrm{CC}$ with the other 5 being $\mathrm{CN}$; of $8 \mathrm{~B}^{\prime} \mathrm{S}^{\prime}$ structures, 7 are right-handed with $\chi_{1}^{1} \chi_{2}^{1}=\mathrm{CC}$; and of $8 \mathrm{BD}$ structures, all are left-handed with $\chi_{1}^{1} \chi_{2}^{1}=\mathrm{CC}$. Some of these preferences have already been noted. ${ }^{8,10}$

An initial view of the tables shows that, of the canonical structures, GG and GT fit the earlier classification $^{1}$ while TT conformations do not: for $\chi_{1}^{1} \chi_{2}^{1}=\mathrm{NN}$ the observable band is near $550 \mathrm{~cm}^{-1}$ while for NC the predominant mode is at $529 \mathrm{~cm}^{-1}$ with another mode near $540 \mathrm{~cm}^{-1}$ being potentially observable. Deviations in dihedral angle of $\sim 30^{\circ}$ are easily tolerable for the GG type (and in one case, $\mathrm{B}^{\prime} \mathrm{S}^{\prime}$, up to $60^{\circ}$ ) without seriously affecting $\nu(\mathrm{SS})$, which means that this region $\left(\sim 510 \mathrm{~cm}^{-1}\right)$ may not be a sensitive determinant of conformation. For structures of the GT type, the situation is different with respect to deviations in dihedral angles: while some $\nu(\mathrm{SS})$ fall within the expected range $(\sim 525$ $\mathrm{cm}^{-1}$ ), others are clearly outside (G'D) or exhibit splittings (SD) that place them in a different category. For the TT type, one variant structure ( $\left.D^{\prime \prime} T\right)$ has a frequency $\left(526 \mathrm{~cm}^{-1}\right)$ that places it in a category to which it does not belong. Thus, we see that caution is clearly needed in applying the proposed classification $^{1}$ to the determination of S-S bridge conformation from the $\nu$ (SS) frequency.

If this classification ${ }^{1}$ cannot be depended on in detail, what can we say about the structural implications of observed $\nu$ (SS) bands? A histogram of the frequency distribution in Table I shows that the $\nu$ (SS) of each conformation are mostly localized in a relatively small frequency region (including each component of the split modes) and that the distribution has four regions in which the frequencies fall: $503-512,512-521,521-529$, and 535-556 $\mathrm{cm}^{-1}$. This leads us to propose the classification scheme given in Table III, which can serve as a reasonable starting point for categorizing conformation from spectrum.

As noted above, the $503-512-\mathrm{cm}^{-1}$ region contains many conformations related to GG by small $\left(\sim 30^{\circ}\right)$ variations in $\chi_{1}^{2}$ and/or $\chi_{2}^{2}$. We have nevertheless subdivided this class into $1 \mathrm{a}\left(503-505 \mathrm{~cm}^{-1}\right)$ and $1 \mathrm{~b}$ (506-512 $\mathrm{cm}^{-1}$ ) since the predominant number of examples ( 10 of 13 ) of the 1a conformations fall in this limited low-frequency range. In all, 53 of 55 examples are encompassed in the entire range. The exception is BB, which contributes also at 513 and $519 \mathrm{~cm}^{-1}$ [ the latter possibly because of a split mode at $491(23) \mathrm{cm}^{-1}$, perhaps because of unusual $\chi_{1}^{1}$ $=48.6^{\circ}, \chi_{2}^{1}=89.3^{\circ} \mathrm{J}$, and in general seems to have broadly spread frequencies. It is interesting that some conformations in class $1 \mathrm{~b}$ span limited frequency ranges ( 9 of 10 examples of GG fall in the $507-509-\mathrm{cm}^{-1}$ range, and 10 of 12 examples of SB', $\mathrm{B}^{\prime} \mathrm{S}^{\prime}$, and GA fall in the 509-511- $\mathrm{cm}^{-1}$ range ), while in one case $\left(\mathrm{B}^{\prime} \mathrm{B}^{\prime}\right)$ both examples fall at the same frequency $\left(506 \mathrm{~cm}^{-1}\right)$.

All of the examples of class 2 conformations fall in the $512-521-\mathrm{cm}^{-1}$ range, including the low-frequency components of the SD structure. Similarly, all of the examples of the class 3 conformations fall in the 521-529- $\mathrm{cm}^{-1}$ range, including (where appropriate) the low-frequency components of $\mathrm{BT}$ and

Table III SS Stretch Frequency Classes of Disulfide Bridges in Proteins

\begin{tabular}{ccl}
\hline Class & Frequency Range $\left(\mathrm{cm}^{-1}\right)$ & \multicolumn{1}{c}{ Conformations $^{\mathrm{a}}$} \\
\hline 1a & $503-505$ & $\mathrm{G}^{\prime} \mathrm{G}, \mathrm{GB}^{\prime}, \mathrm{G}^{\prime} \mathrm{B}, \mathrm{B}^{\prime} \mathrm{B}$ \\
1b & $506-512$ & $\mathrm{~B}^{\prime} \mathrm{B}^{\prime}, \mathrm{GG}, \mathrm{GB}, \mathrm{SB}^{\prime}, \mathrm{B}^{\prime} \mathrm{S}^{\prime}, \mathrm{BB}, \mathrm{GA}, \mathrm{SS}^{\prime}$ \\
2 & $512-521$ & $\left.\mathrm{GS}, \mathrm{G} \mathrm{C}, \mathrm{G}^{\prime} \mathrm{D}^{\prime}, \mathrm{BD}, \mathrm{B}^{\prime} \mathrm{T}, \mathrm{SD}\right)$ \\
3 & $521-529$ & $\mathrm{AT}, \mathrm{G}^{\prime} \mathrm{T}, \mathrm{GT}, \mathrm{D}^{\prime} \mathrm{T}, \mathrm{SD},(\mathrm{BT}),(\mathrm{TT})$ \\
4 & $535-556$ & (SD), DT, (BT), (TT) \\
\hline
\end{tabular}

a Letters in parentheses: Conformation gives split v (SS) modes. 
TT (BT may also contribute an observable band at $\left.506 \mathrm{~cm}^{-1}\right)$.

We place in class 4 the high-frequency bands, which are primarily of those conformations that can give rise to split $\nu$ (SS) modes. Such splittings and the relative PEDs seem to be sensitive to both $\chi^{1}$ and $\phi, \psi^{7}$, as can be seen from Table I. In one case, DT, no splitting occurs, perhaps because of the unusual $\chi_{1}^{1}=126.3^{\circ}, \chi_{2}^{1}=109.3^{\circ}$ in this case. As noted above, the frequencies of this class do not fit into the simple classification proposed earlier. ${ }^{1}$

\section{CONCLUSIONS}

On the basis of satisfactory agreement between observed Raman bands and $\nu$ (SS) modes calculated for known S-S bridges, ${ }^{6}$ we feel that the present calculations of such modes for $92 \mathrm{~S}-\mathrm{S}$ bridges in known protein structures ${ }^{9}$ provides an accurate representation of the relationship between the $\nu$ (SS) frequency and the CCSS dihedral angles of the bridge.

We see that this relationship is more complex than previously proposed, ${ }^{1}$ but that a classification scheme is nevertheless possible. Although the correlations somewhat complicate the spectrum-conformation deductions, they do provide deeper insights into the conclusions that can be drawn. This could be valuable in interpreting the detailed conformational changes associated with frequency shifts in $\nu$ (SS) modes that result from changes in the structure of a protein.

This research was supported by NSF grants DMB-8816756 and DMR-8806975.

\section{REFERENCES}

1. Sugeta, H., Go, A. \& Miyazawa, T. (1972) Chem. Lett. 83.

2. Zhao, W., Bandekar, J. \& Krimm, S. (1988) J. Am. Chem. Soc. $110,6891-6892$.

3. Zhao, W. \& Krimm, S. (1990) J. Mol. Struct. 224, 7-20.

4. Zhao, W., Bandekar, J. \& Krimm, S. (1990) J. Mol. Struct. 238, 43-54.

5. Krimm, S. \& Bandekar, J. (1986) Adv. Protein Chem. 38, 181-364.

6. Qian, W., Zhao, W. \& Krimm, S. (1991) J. Mol. Struct. 250, 89-102.

7. Qian, W. \& Krimm, S., Biopolymers, in press.

8. Srinivasan, N., Sowdhamini, R., Ramakrishnan, C. \& Balaram, P. (1990) Int. J. Peptide Protein Res. 36, 147-155.

9. Bernstein, F. C., Koetzle, T. F., Williams, G. J. B., Meyer, E. F., Brice, M. D., Rodgers, J. R., Kennard, O., Shimanouchi, T. \& Tasumi, M. (1977) J. Mol. Biol. 112, 535-542.

10. Richardson, J. S. (1981) Adv. Protein Chem. 34, 167239.

Received June 10, 1991

Accepted August 6, 1991 